\title{
UPAYA PENINGKATAN KOMPETENSI GURU MENULIS HAND OUT MELALUI IN HOUSE TRAINING DI MASA PANDEMI
}

\author{
Osnely Jasmi \\ Kepala SMPN 1 Kec. Lareh Sago Halaban Kabupaten Lima Puluh Kota \\ Email: osnelyjasmi@gmail.com
}

\begin{abstract}
This study aims to determine the increase in teacher competency at SMPN 1 Kecamatan Lareh Sago Halaban, Kabupaten Lima Puluh Kota in mahing hand out through IHT activities. The subjects of this study were all teachers in SMPN 1 Kecamatan Lareh Sago Halaban. This research is School Action Research (PTS) which consists of two cycles, each cycle covering the stages of planning, implementation, observation and reflection. The data analysis technique used is descriptive comparative. The study shows the average in cycle 1 is $54 \%$ and cycle 2 is $88 \%$. From the results of the study it can be concluded that: IHT can improve the competence of teachers at SMPN 1 Kecamatan Lareh Sago Halaban in making hand out.
\end{abstract}

Keywords: teacher competence, hand out, in house training

Abstrak

Penelitian ini bertujuan untuk melihat peningkatan kemampuan guru SMP Negeri 1 Kecamatan Lareh Sago Halaban, Kabupaten Lima Puluh Kota dalam menulis bahan ajar berbentuk hand out melalui kegiatan IHT (in house training). Subjek pada penelitian ini adalah seluruh guru SMP Negeri 1 Kecamatan Lareh Sago Halaban Kabupaten Lima Puluh Kota. Penelitian ini berbentuk Penelitian Tindakan Sekolah (PTS) yang terdiri dari dua siklus, setiap siklus terdiri dari empat tahapan yaitu perencanaan, tindakan, observasi dan refleksi. Teknik analisa data yang digunakan adalah deskriptif komparatif. Hasil penelitian pada siklus ke 1 rata-rata porsentase $54 \%$ dan pada siklus ke 2 rata-rata porsentase $88 \%$ sehingga dapat disimpulkan terjadi kenaikan sebesar 34\%. Dari hasil penelitian siklus satu dan siklus dua dapat disimpulkan bahwa IHT dapat meningkatkan kemampuan guru SMP Negeri 1 Kecamatan Lareh Sago Halaban dalam menulis hand out.

Kata kunci: kompetensi guru, hand out, in house training

\section{PENDAHULUAN}

Awal tahun 2020 dunia dikejutkan dengan wabah yang melanda, tak pelak Indonesia juga mengalaminya. Corona virus disesase atau yg lebih dikenal dengan covid -19 menyebar ke seluruh dunia dalam waktu singkat. Jutaan orang terpapar, ratusan ribu manusia meninggal dunia, dunia kesehatan kewalahan menangani pasien , semua sektor luluh lantak termasuk dunia pendidikan. Dengan berbagai pertimbangan maka pemerintahpun memutuskan untuk menutup sekolah dalam upaya untuk memutus rantai penularan wabah penyakit ini.

Proses pembelajaran di sekolah merupakan alat kebijakan publik terbaik sebagai upaya peningkatan pengetahuan dan ketrampilan. Selain itu banyak siswa menganggap bahwa sekolah adalah kegiatan yang sangat menyenangkan, mereka 
bisa berinteraksi satu sama lain. Sekolah dapat meningkatkan keterampilan sosial dan kesadaran kelas sosial siswa. Sekolah secara keseluruhan adalah media interaksi antar siswa dan guru untuk meningkatkan kemampuan intelegensi, ketrampilan dan rasa kasih sayang diantara mereka. Tetapi sekarang kegiatan yang bernama sekolah berhenti dengan tiba-tiba karena gangguan Covid-19.

Sekolah diharapkan menggunakan media daring. Namun, penggunaan teknologi bukan tidak ada masalah, banyak varians masalah yang menghambat terlaksananya efektivitas pembelajaran dengan metode daring diantaranya adalah: 1) Keterbatasan penguasaan teknologi informasi baik dari kalangan guru maupun siswa, Kendala teknologi informasi membatasi mereka dalam menggunakan media daring. 2) Sarana dan Prasarana yang kurang memadai. Perangkat pendukung teknologi jelas mahal yang bisa menjadi salah satu faktor penyebab tidak dapat terlaksananya pembelajaran daring. 3) Akses Internet yang terbatas. Jaringan internet yang benar-benar masih belum merata di pelosok negeri.

Kementerian Pendidikan dan Kebudayaan RI telah melakukan berbagai upaya untuk tetap berjalannya Kegiatan Belajar Mengajar (KBM) di tengah Pandemi Covid-19, diantaranya dengan diterbitkannya Surat Edaran Nomor 4 tahun 2020 Kementerian Pendidikan yang memuat tentang empat pokok utama strategi pendidikan di Indonesia: Pertama adalah pembelajaran secara daring, baik secara interaktif maupun non interaktif. Hal ini perlu dilakukan meskipun tidak semua anak-anak dapat melakukan itu karena faktor infrastruktur. Kedua adalah tenaga pengajar atau guru harus memberikan pendidikan kepada anak-anak tentang kecakapan hidup, yakni pendidikan yang bersifat kontekstual sesuai kondisi rumah masing-masing, terutama pengertian tentang Covid-19, mengenai karakteristik, cara menghindarinya dan bagaimana cara agar seseorang tidak terjangkit.Ketiga adalah pembelajaran di rumah harus disesuaikan dengan minat dan kondisi masing-masing anak. Keempat adalah bagi para tenaga pengajar atau guru, tugas-tugas yang diberikan kepada siswa tidak harus dinilai seperti biasanya di Sekolah, akan tetapi penilaian lebih banyak kualitatif yang sifatnya memberi motivasi kepada anak-anak.

Bertolak dari permasalahan di atas maka sekolah sebagai garda terdepan dalam bidang pendidikan harus mengambil langkah konkrit agar tetap berjalannya proses pembelajaran dan terwujudnya pendidikan yang berkualitas. Sekolah diharapkan menyusun strategi yang tepat dengan tetap mempertimbangkan kondisi sekolah masing-masing baik berupa sumber daya manusia, serta sarana prasarana yang mendukung serta tetap mengacu pada Standar Proses seperti yang tertuang pada Permendikbud nomor 22 tahun 2016.

SMPN 1 Kecamatan Lareh Sago Halaban terletak di lereng Gunung Sago Kabupaten Lima Puluh Kota, mayoritas siswanya berasal dari keluarga golongan menengah ke bawah, dan dengan berbekal pengalaman sejak awal pendemi yang dimulai pada bulan Maret maka sekolah melakukan evaluasi diri untuk menentukan langkah kedepan dalam upaya mempersiapkan diri agar proses pembelajaran dapat berjalan secara terprogram dan terencana. Sesuai dengan kebijakan pemerintah SMPN 1 Kecamatan Lareh Sago Halaban melaksanakan pembelajaran jarak jauh secara daring dan luring. Siswa yang memiliki sarana komunikasi seperti handphone android dan akses internet dapat melaksanakan pembelajaran secara daring tetapi bagi siswa yang tidak memiliki handphone atau kesulitan dalam akses internet maka pembelajaran dilaksankan secara luring. 
Pembelajaran jarak jauh baik daring atau luring lebih banyak mengharapkan siswa belajar secara mandiri maka siswa harus dibekali dengan sumber belajar yang memudahkan mereka untuk memahami pelajaran. Sumber belajar tersebut adalah dengan menggunakan hand out.

Hasil evaluasi diri yang dilaksanakan di SMPN 1 Kecamatan Lareh Sago Halaban menunjukkan bahwa guru PNS berjumlah 31 orang dan guru honorer 15 orang dengan jumlah rombongan belajar sebanyak 24 kelas. Ditinjau dari segi umur maka $80 \%$ dari guru PNS berusia diatas 50 tahun. Hasil evaluasi diri terhadap perangkat pembelajaran guru PNS dan honorer menunjukkan bahwa 3 orang guru PNS yang membuat bahan ajar sementara yang lainnya menggunakan LKS yang disediakan oleh penerbit. Dari hasil evaluasi diri terlihat bahwa guruguru kurang memahami bagaimana membuat bahan ajar berbentuk handout.

Handout berasal dari bahasa Inggris yang berarti informasi, berita atau surat lembaran. Handout termasuk media cetak yang meliputi bahan-bahan yang disediakan di atas kertas untuk pengajaran dan informasi belajar. Biasanya diambil dari beberapa literatur yang memiliki relevansi dengan materi yang diajarkan/kompetensi dasar dan materi pokok yang harus dikuasai oleh peserta didik.

Istilah Handout memang belum ada padanannya dalam bahasa Indonesia. Handout biasanya merupakan bahan ajar tertulis yang diharapkan dapat mendukung bahan ajar lainnya atau penjelasan dari guru. Handout adalah bahan tertulis yang disiapkan oleh seorang guru untuk memperkaya pengetahuan peserta didik.

Guru yang profesional harus memiliki 4 kompetensi seperti tertuang dalam Peraturan Menteri Pendidikan Nasional Nomor 16 tahun 2007 yaitu Kompetensi pedagogik, kompetensi kepribadian, kompetensi sosial dan kompetensi profesional. Salah satu poin dalam kompetensi profesional yaitu guru harus memiliki kemampuan dalam mengembangkan materi pembelajaran yang diampu secara kreatif, dan memilih materi pembelajaran yang diampu sesuai dengan tingkat perkembangan peserta didik, serta di era pandemi ini siswa dituntut untuk mampu belajar secara mandiri. Agar guru SMPN 1 Kecamatan Lareh Sago Halaban dapat menulis handout yang baik perlu adanya pelatihan, dan bentuk pelatihan yang akan dilaksanakan adalah in house training.

Keunggulan in house training karena dilakukan di lokasi tempat kerja (di sekolah) dan menggunakan pendekatan yang fleksibel sesuai dengan kebutuhan para guru sehingga dalam pelaksanaannya guru merasa lebih nyaman dan mampu terlibat secara aktif dalam proses pelatihan. Alasan ini sejalan dengan hasil penelitian yang menunjukkan bahwa pelatihan yang efektif adalah yang didasarkan pada konstruktivisme bukan pada model yang berorientasi transmisi (transmission oriented model) dimana mampu melibatkan sebagai pembelajar aktif (Lieberman, dalam Baharudin, 2017) dan terkait langsung dengan tugas-tugas konkret mengajar, penilaian, observasi dan refleksi yang dilakukan oleh guru dalam setiap harinya. Basis utama in house training adalah kontekstual sehingga muatan atau konten materi yang disajikan disesuaikan dengan kebutuhan guru di sekolah. Prinsip ini bertentangan dengan pengembangan guru/staf tradisional yang kebanyakan tidak berhubungan antara jenis pelatihan yang diikuti dengan pengalaman kelas yang sebenarnya. 
In house training merupakan program pelatihan yang diselenggarakan di tempat sendiri sebagai upaya untuk meningkatkan kompetensi guru, dalam menjalankan pekerjaannya dengan mengoptimalkan potensi-potensi yang ada (Sujoko dalam Baharudin, 2017). In house training adalah jenis pelatihan yang dilaksanakan secara internal oleh kelompok kerja guru, sekolah atau tempat lain yang ditetapkan sebagai penyelenggaraan pelatihan yang dilakukan berdasar pada pemikiran bahwa sebagian kemampuan dalam meningkatkan kompetensi dan karier guru tidak harus dilakukan secara eksternal, namun dapat dilakukan secara internal oleh guru sebagai trainer yang memiliki kompetensi yang lebih dari guru lainnya.

Kirkpatrick (Jayadipura, 2018) mendefinisikan bahwa In House Training adalah pelatihan yang dilaksanakan atas permintaan suatu kelompok tertentu, apakah itu lembaga profit ataupun nonprofit . Sedangkan Ayuningtyas (Jayadipura, 2018) menyatakan bahwa In House Training (IHT) merupakan program yang diselenggarakan di sekolah atau tempat lain menggunakan peralatan dan materi yang relevan dengan permasalahan yang dihadapi, tujuannya adalah untuk mengembangkan kompetensi berupa skill, knowledge, dan atittude. Hal senada diungkapkan (Corinorita dalam Baharudin 2017) In house training merupakan program pelatihan yang diselenggarakan di tempat sendiri, sebagai upaya untuk meningkatkan kompetensi guru, dalam menjalankan pekerjaannya dengan mengoptimalkan potensi-potensi yang ada. Berdasarkan pemaparan-pemaparan tersebut dapat disimpulkan bahwa IHT merupakan program yang diselenggarakan di lingkungan sendiri menggunakan peralatan dan materi yang relevan dengan permasalahan yang dihadapi, sebagai upaya untuk meningkatkan kompetensi yang dibutuhkan. Tujuan penelitian ini adalah untuk mengetahui apakah melalui kegiatan IHT, guru dapat meningkatkan kompetensinya dalam menyusun hand out sesuai mata pelajarannya masing-masing.

\section{METODE PENELITIAN}

Penelitian Tindakan Sekolah (PTS) dilaksanakan di SMPN 1 Kecamatan Lareh Sago Halaban.Penelitian Tindakan sekolah ini dilaksanakan pada semester I tahun pelajaran 2020/2021 adapun waktu penelitiannya adalah Juni sampai dengan Agustus 2020. Subjek penelitian adalah guru SMPN 1 Kecamatan Lareh Sago Halaban sebanyak 46 orang guru yang terdiri dari 31 orang guru PNS dan 15 orang guru honorer. Tehnik dalam penelitian ini adalah wawancara, observasi, diskusi dan studi dokumentasi sedangkan alat pengumpulan data dalam Penelitian Tindakan sekolah ini sebagai berikut : (a) wawancara menggunakan panduan wawancara untuk mengetahui kemampuan awal yang dimiliki guru tentang penyusunan hand out, (b) observasi menggunakan lembar observasi untuk mengetahui komponen - komponen hand out yang dibuat oleh guru, (c) diskusi dilakukan dengan maksud untuk sharing pendapat antara peneliti dan guru (d) studi dokumentasi .

Penelitian ini berbentuk Penelitian Tindakan Sekolah (PTS) . Metode yang digunakan dalam penelitian ini adalah metode deskriptif, dengan menggunakan tehnik persentase untuk melihat peningkatan yang terjadi dari siklus ke siklus. "Metode deskriptif dapat diartikan sebagai prosedur pemecahan masalah yang diselidiki dengan menggambarkan/ melukiskan keadaan subjek/objek penelitian ( seseorang, lembaga, masyarakat,dan lain lain) pada saat sekarang berdasarkan 
fakta-fakta yang tampak atau sebagaimana adanya . Kemmis dan Mc Taggart dalam Mohammad Asrori (2019) menjelaskan proses penelitian dilaksanakan bersiklus, setiap siklusnya terdiri dari empat tahap yaitu: (1) perencanaan, (2) pelaksanaan, (3) pengamatan, (4) refleksi. Pada tahap Perencanaan dilakukan tindakan berupa : (a) wawancara dengan guru dengan menyiapkan lembar wawancara. (b) studi dokumentasi tentang kelengkapan perangkat pembelajaran guru. Tahap Pelaksanaan berupa kegiatan In House Training yang dilaksanakan dengan mengundang nara sumber widyaswara dari pihak LPMP Sumatera Barat tanggal 29 dan 30 Juni 2020 dengan materi penyusunan hand out (Siklus 1). Pada tahap ini guru-guru dibimbing dan dilatih bagaimana menyusun hand out yang baik. Kegiatan in house training akan dilanjutkan ke Siklus 2 atau siklus ke-3 apabila indikator keberhasilan belum tercapai pada siklus 1 atau siklus 2. Sebaliknya kegiatan penelitian akan dihentikan apabila indikator keberhasilan sudah tercapai pada siklus ke-2 atau ke-3. Pada tahap Observasi, peneliti melakukan kegiatan pengamatan terhadap hand out yang dibuat oleh guru dan studi dokumentasi untuk memotret seberapa jauh kemampuan guru dalam menyusun hand out telah meningkat. Tahap Refleksi digunakan untuk mengkaji, melihat dan mempertimbangkan hasil atau dampak dari tindakan yang telah dilakukan.

Penelitian tindakan sekolah (PTS) merupakan penelitian yang bersiklus, artinya penelitian dilakukan secara berulang dan berkelanjutan sampai tujuan penelitian tercapai. Alur kegiatan Penelitian tindakan sekolah dapat dilihat pada gambar berikut :

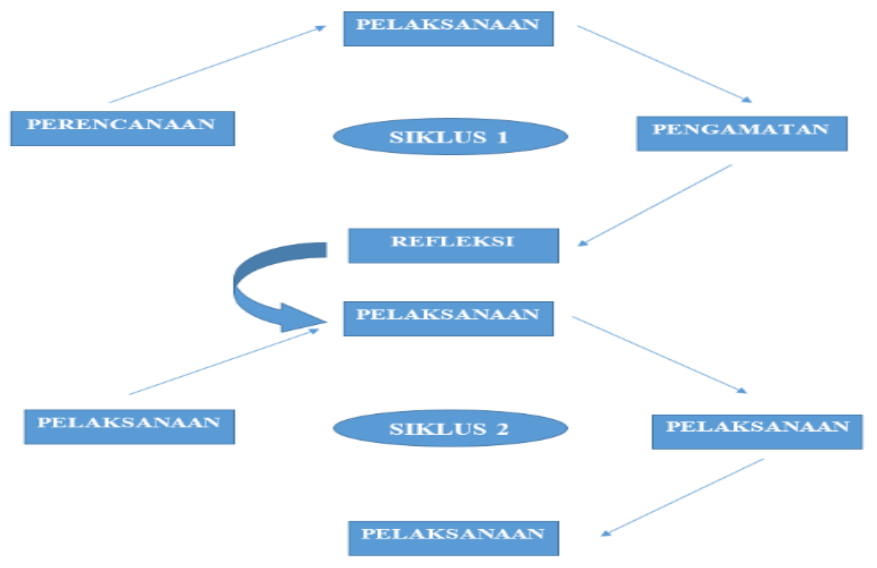

\section{Gambar 1. Alur Penelitian Tindakan Sekolah (Model Kemmis dan Mc Taggart dalam Waitlem dan Risman, 2017 )}

Teknik pengumpulan data yang digunakan melalui teknik non tes, dengan menggunakan instrumen pengumpul data yaitu lembar observasi. Lembar observasi digunakan untuk mengetahui jumlah guru yang menyusun Hand Out dan persentasenya. Teknik Analisis Data menggunakan Teknik persentase . Teknik persentase digunakan menganalisa data jumlah guru dalam menyusun Hand Out dengan rumus :

Persentase Keberhasilan $=$ Jumlah guru menyusun HO $\quad$ x $100 \%$ 
Data hasil observasi diolah dengan persentase dengan kriteria seperti pada tabel dibawah ini:

\begin{tabular}{|l|l|}
\hline \multicolumn{2}{|c}{ Interval Penilaian } \\
\begin{tabular}{|l|l|} 
Persentase & Sebutan \\
( Kuantitatif $)$
\end{tabular} & Kurang \\
\hline $0 \leq \mathrm{AB}<50$ & Cukup \\
$50 \leq \mathrm{AB}<75$ & Baik \\
$75 \leq \mathrm{AB}<90$ & Amat Baik \\
$90 \leq \mathrm{AB}<100$ & \\
\hline
\end{tabular}

Penelitian ini dikatakan berhasil apabila jumlah guru yang menyusun hand out mencapai $\geq 75 \%$ dengan kategori BAIK.

\section{HASIL PENELITIAN DAN PEMBAHASAN Penelitian Siklus 1}

Sebagai data awal dipaparkan bahwa guru SMPN 1 Kecamatan Lareh Sago Halaban berjumlah 46 orang dengan rincian 31 orang PNS dan 15 orang honorer . Hasil supervisi perangkat pembelajaran menunjukkan bahwa jumlah guru yang menggunakan bahan ajar/ hand out yang dibuat sendiri hanya 3 orang yaitu sebesar $6 \%$, serta dari hasil wawancara dengan guru didapat data bahwa guru kurang memahami bagaimana menyusun hand out maka dilaksanakan penelitian dengan hasil sebagaimana disampaikan berikut ini.

Pertemuan ke-1 dilaksanakan pada hari Senin, 29 Juni 2020 mulai pukul 08.00 WIB s.d 21.00 WIB dengan jumlah peserta yang hadir 46 orang. Peneliti memulai dengan memberikan arahan tentang pentingnya mempersiapkan perangkat pembelajaran karena semboyan yang peneliti pakai dalam pelaksanaan tugas keguruan adalah "Masuk tanpa persiapan, Keluar tanpa penghormatan" serta dalam era pandemi saat ini perangkat pembelajaran harus disesuaikan dengan pembelajaran jarak jauh seperti tertuang dalan surat edaran Mentri Pendidikan dan Kebudayaan nomor 4 tahun 2020. Nara sumber yang merupakan widyaswara dari Lembaga Penjaminan Mutu Pendidikan Propinsi melatih sebanyak 46 orang guru . Kegiatan dimulai dari memberikan pemahaman tentang TUPOKSI (Tugas Pokok dan Fungsi) guru, penyusunan RPP sebagai dasar penyusunan Hand Out dan secara perlahan membimbing guru menyusun hand out. Nara sumber memberikan arahan dan meminta guru langsung bekerja dalam menyusun hand out. Seluruh guru membawa laptop untuk bekerja dan selangkah demi selangkah nara sumber membimbing guru-guru dalam penyusunan hand out.

Pertemuan ke-2 dilaksanakan pada hari Selasa, 30 Juni 2020. Kegiatan tetap dimulai pada jam 08.00 WIB. Pada pertemuan kedua ini kegiatan berupa melanjutkan kegiatan penyusunan hand out dan guru diminta untuk menayangkan handout yang telah disusun. Pada kesempatan ini hanya dapat menayangkan 10 handout (1 untuk masing-masing mata pelajaran). hasil penayangan yang ditampilkan masih banyak ditemui kesalahan atau kekeliruan dalam penyusunan handout. Guru 10, guru 22 dan guru 34 kurang tepat dalam menyusun peta konsep sehingga membuat uraian materinya tidak tepat sasaran. Narasumber kembali 
memberikan pengarahan penyusunan handout dan menganalisa kesalahan guru. Selama pelaksanaan, peneliti mengamati jalannya kegiatan IHT dan membantu nara sumber dalam membimbing guru-guru. Seluruh guru diberikan waktu kurang lebih 10 hari untuk menyelesaikan handout. Awal tahun pelajaran baru guru diminta untuk mengumpulkan perangkat pembelajaran termasuk hand out.

Setelah dilakukan pemeriksaan terhadap hand out yang disusun oleh guru maka didapat hasil sebagai berikut: Jumlah guru yang menyerahkan atau menyusun hand out adalah 27 orang (59\%); jumlah guru yang menyusun hand out dengan kriteria baik berjumlah 22 orang (48\%). Data diatas dibandingkan dengan data awal (pra siklus) dapat digambarkan seperti tabel berikut ini:

Tabel 1. Jumlah guru yang menyusun dan penilaian handout serta persentase pada pra siklus dan siklus 1.

\begin{tabular}{ccccccccc}
\hline & \multicolumn{3}{c}{ SIKLUS 1 } & \multicolumn{3}{c}{ SIKLUS 2 } \\
\hline No. & $\begin{array}{c}\text { Jumlah } \\
\text { Guru }\end{array}$ & $\%$ & $\begin{array}{c}\text { Nilai HO } \\
\text { Baik }\end{array}$ & $\%$ & $\begin{array}{c}\text { Jumlah } \\
\text { Guru }\end{array}$ & $\begin{array}{c}\% \\
\text { Nilai HO } \\
\text { Baik }\end{array}$ & $\%$ \\
$\mathbf{1}$ & 3 orang & $6 \%$ & 0 & $0 \%$ & 27 orang & $59 \%$ & 22 orang & $48 \%$ \\
\hline
\end{tabular}

Untuk lebih mudah memahaminya, data diatas disajikan dalam bentuk grafik seperti pada Gambar 1 di bawah ini :

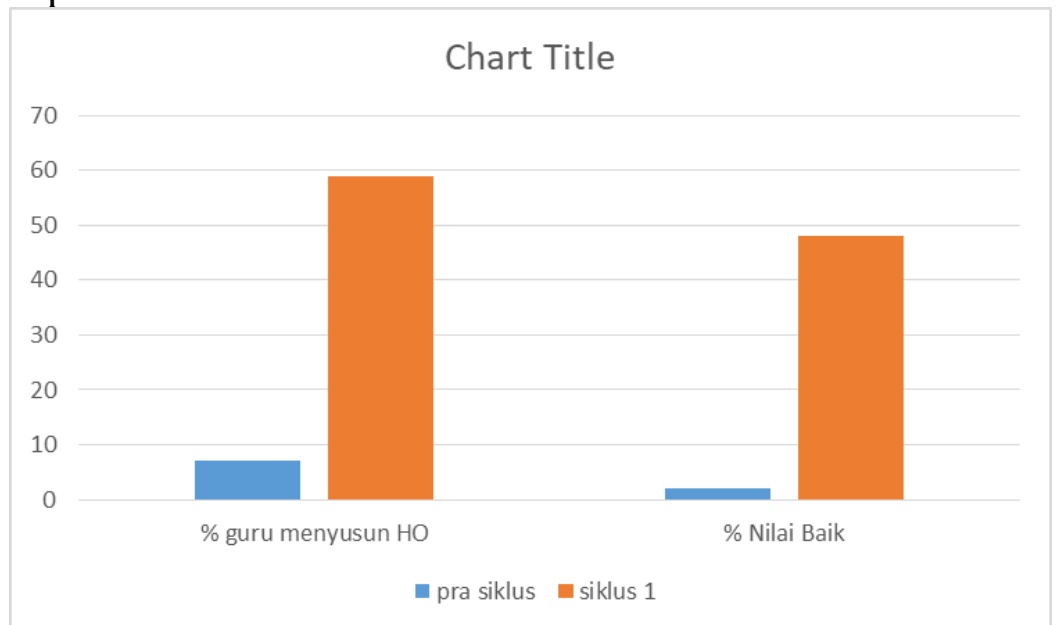

Grafik 1. Persentae guru menyusun hand out dan penilaian hand out pada materi pembelajaran pada pra siklus dan siklus 1 .

Dari grafik diatas dapat disimpulkan bahwa pada siklus 1 terdapat peningkatan jumlah guru yang menyusun hand out sebanyak 27 orang (59\%) jika dibandingkam dengan pra siklus sebanyak 3 orang $(6 \%)$ dan jumlah guru yang mendapat nilai baik dalam penyusunan hand out sebanyak 22 orang (48\%) . Hasil pengamatan terhadap hand out yang disusun oleh guru-guru masih ditemukan beberapa kekurangan seperti: a. Kurang tepat dalam merumuskan tujuan pembelajaran, Rumusan tujuan pembelajaran sebaiknya menggambarkan proses dan hasil sementara rumusan tujuan pembelajaran yang dibuat hanya menggambarkan hasil sejumlah 5 orang guru (11\%); b. 7 orang guru (15\%) masih mengalami kekurangan dalam membuat peta konsep; dan c. sebanyak 12 orang (26\%) dalam membuat uraian materi masih terlalu umum dan ringkas sehingga 
belum terpenuhinya penyusunan hand out yang baik. Hasil yang diperoleh pada siklus 1 dibandingkan dengan pra siklus dapat dipaparkan bahwa terdapat peningkatan yang tinggi dalam jumlah guru yang menyusun hand out yaitu peningkatan sebesar 53\% dan jumlah guru yang dapat menyusun hand out dengan nilai baik terdapat peningkatan sebesar 59\%, namun kriteria ketercapaian belum terpenuhi sehingga penelitian perlu dilanjutkan pada siklus 2. Kegiatan IHT pada siklus 2 akan lebih difokuskan pada kelemahan yang ditemui baik berdasarkan pantauan dari hasil hand out ataupun berdasarkan wawancara dengan guru yaitu dalam perumusan tujuan pembelajaran, membuat peta konsep dan penjabaran pada uraian materi.

\section{Siklus 2.}

Tindakan siklus 2 merupakan upaya perbaikan terhadap tindakan siklus 1 . Tahapan yang dilaksanakan sama dengan tahapan pada siklus 1, namun pada siklus 2 ada beberapa hal yang perlu penekanan, yaitu: a. kepala sekolah agar lebih mendorong guru untuk menyusun hand out b. rumusan tujuan pembelajaran agar diperhatikan c. pembuatan peta konsep d. penjelasan dalam uraian materi.

Pertemuan untuk siklus 2 dilaksanakan hari Senin tanggal 27 Juli 2020. Pada pertemuan ini tidak didatangkan nara sumber tetapi peneliti sebagai kepala sekolah langsung membimbing guru-guru dalam menyusun hand out karena peneliti cukup memahami tentang penyusunan hand out baik yang didapat selama mendampingi nara sumber pada siklus 1 dan juga studi literatur yang dilakukan tentang hand out. Peneliti memulai kegiatan IHT dengan memberikan arahandan motivasi tentang pentingnya penyusunan hand out dalam era pandemi. Siswa agar dibekali dengan bahan pembelajaran yang dirancang sesuai dengan kebutuhan pembelajaran jarak jauh (PJJ). Siswa sangat membutuhkan hand out yang ditulis oleh guru mereka sendiri karena kita selaku guru mengetahui kemampuan mereka, maka kita akan menyusun hand out dengan bahasa yang mudah mereka pahami. Pembelajaran jarak jauh menuntut siswa untuk belajar secara mandiri. Pembahasan dilanjutkan tentang kesulitankesulitan yang dihadapi guru dalam penyusunan hand out. Rumusan tujuan pembelajaran yang menggambarkan proses dan hasil ditayangkan, seperti pada mata pelajaran Pendidikan Agama Islam. Melalui kegiatan membaca hand out peserta didik dapat menjelaskan dasar hukum sujud syukur, sujud sahwi dan sujud tilawah dengan benar. Dari rumusan tujuan ini dapat dilihat bahwa bentuk proses pembelajarannya adalah membaca hand out dan hasil yang diharapkan adalah siswa mampu menjelaskan dasar hukum sujud syukur, sujud sahwi dan sujud tilawah. Guru diberi kesempatan untuk merumuskan tujuan pembelajarannya masing-masing. Pembahasan berikutnya tentang peta konsep dan terahkir tentang penjabaran pada uraian materi. Setelah melakukan serangkaian kegiatan penguatan pada guru kemudian guru diberi kesempatan untuk menyusun hand out sesuai dengan arahan yang telah diberikan. Kegiatan IHT pada siklus 2 ini berjalan dengan lancar. 
Hari Kamis, 30 Juli 2020 guru- guru diminta mengumpulkan hand out ke 2. Hand out yang telah disusun dievaluasi dan hasilnya seperti tertuang pada tabel 2. berikut:

Tabel 2. Jumlah guru yang menyusun dan penilaian hand out serta persentase pada siklus 1 dan siklus 2.

\begin{tabular}{ccccccccc}
\hline & \multicolumn{3}{c}{ SIKLUS 1 } & \multicolumn{3}{c}{ SIKLUS 2 } \\
\hline No. & $\begin{array}{c}\text { Jumlah } \\
\text { Guru }\end{array}$ & $\begin{array}{c}\text { Nilai HO } \\
\text { Baik }\end{array}$ & $\%$ & $\begin{array}{c}\text { Jumlah } \\
\text { Guru }\end{array}$ & $\begin{array}{c}\% \\
\text { Nilai HO } \\
\text { Baik }\end{array}$ & $\%$ \\
$\mathbf{1}$ & 27 orang & $59 \%$ & 22 orang & $48 \%$ & 43 orang & $93 \%$ & 38 orang & $83 \%$ \\
\hline
\end{tabular}

Untuk lebih mudah memahaminya, data diatas disajikan dalam bentuk grafik seperti pada Gambar 2 di bawah ini.

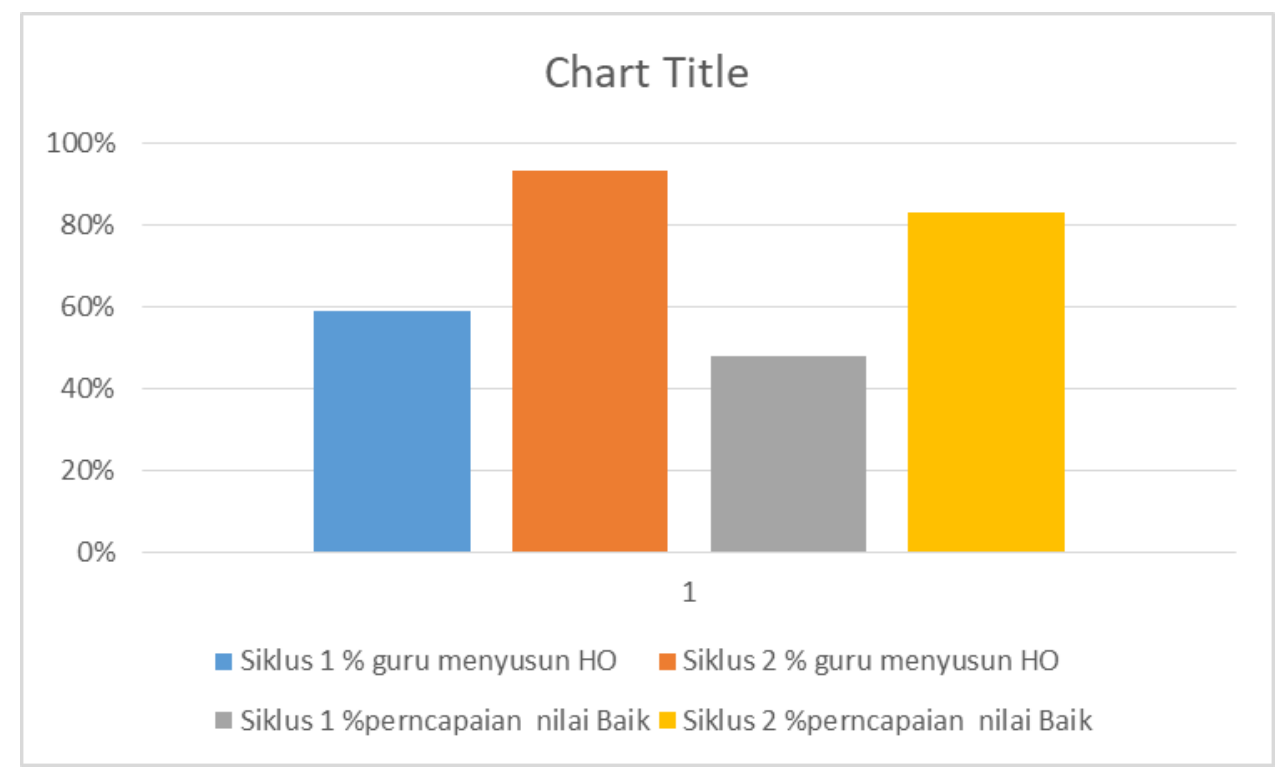

Gambar 2. Persentae guru menyusun hand out dan penilaian hand out pada materi pembelajaran siklus 1 dan siklus 2 .

Dari grafik diatas dapat dipaparkan bahwa hasil yang telah dicapai pada siklus 2 yaitu jumlah guru yang sudah membuat hand out sebanyak 43 orang (93\%) dan jumlah guru yang penilaian terhadap hand out yang disusunnya memiliki prediket Baik 38 orang (83\%). Dari hasil yang dicapai pada siklus 2 yaitu sebesar $93 \%$ guru sudah mampu menyusun hand out dan $83 \%$ guru sudah memperoleh prediket baik dalam penyusunan hand out maka penelitian sudah dapat dihentikan karena sudah melebihi indikator pencapaian baik untuk jumlah guru yang menyusun hand out dan jumlah guru yang mendapat nilai baik pada penyusunan hand out yaitu $75 \%$.

\section{Pembahasan}

Pembelajaran jarak jauh sangat membutuhkan bahan belajar khusus yang dapat membantu siswa belajar secara mandiri di rumah, dan penggunaan hand out dapat dijadikan sebagai sarana pemenuhan kebutuhan siswa tersebut . Dari data survey perangkat pembelajaran di SMPN 1 Kec. Lareh Sago Halaban ditemukan 
bahwa hanya 3 orang guru yang menyiapkan bahan ajar kepada siswa sehingga perlu untuk dilaksanakan In House Training (IHT) dalam upaya meningkatkan kemampuan guru - guru dalam menyusun hand out. Setelah pelaksanaan tindakan pada siklus 1 seperti tertuang pada Tabel 3 dapat disimpulkan bahwa terjadi peningkatan yang cukup signifikan terhadap kemampuan guru menyusun handout. Pada pra siklus porsentase guru yang menyusun hand out $6 \%$ meningkat menjadi 59\% pada siklus 1 dalam hal ini terdapat peningkatan sebesar 53\% dan kemampuan guru menyusun handout pada siklus 2 menjadi 93\%. Hal ini menunjukkan terdapatnya peningkatan sebesar $34 \%$. Hand out yang telah dibuat dinilai sesuai dengan instrumen penilaian hand out dengan hasil sebagai berikut: pra siklus $0 \%$ dan hasil pada siklus 1 sebesar $48 \%$, ini menunjukkan terdapatnya peningkatan sebesar $48 \%$ dan pada siklus 2 dengan hasil $83 \%$. Dari data tersebut dapat disimpulkan bahwa terdapat peningkatan sebesar 35\% seperti terlihat pada grafik berikut ini:

Tabel 3. Jumlah guru yang menyusun dan penilaian hand out serta persentase pada pra siklus, siklus 1 dan siklus 2.

\begin{tabular}{clccccc}
\hline No. & SIKLUS PTS & $\begin{array}{c}\text { Jumlah } \\
\text { Guru } \\
\text { (orang) }\end{array}$ & $\begin{array}{c}\text { Nilai HO } \\
\text { Baik } \\
\text { (orang) }\end{array}$ & \% & $\begin{array}{c}\text { Peningkatan } \\
\text { (\%) }\end{array}$ \\
\hline 1. & PRA SIKLUS & 3 & 6 & 0 & 0 & 0 \\
2. & SIKLUS 1 & 27 & 59 & 22 & 48 & 48 \\
3. & SIKLUS 2 & 43 & 93 & 38 & 83 & 35 \\
\hline
\end{tabular}

Untuk lebih mudah memahaminya, data diatas disajikan dalam bentuk grafik seperti pada grafik di bawah ini :

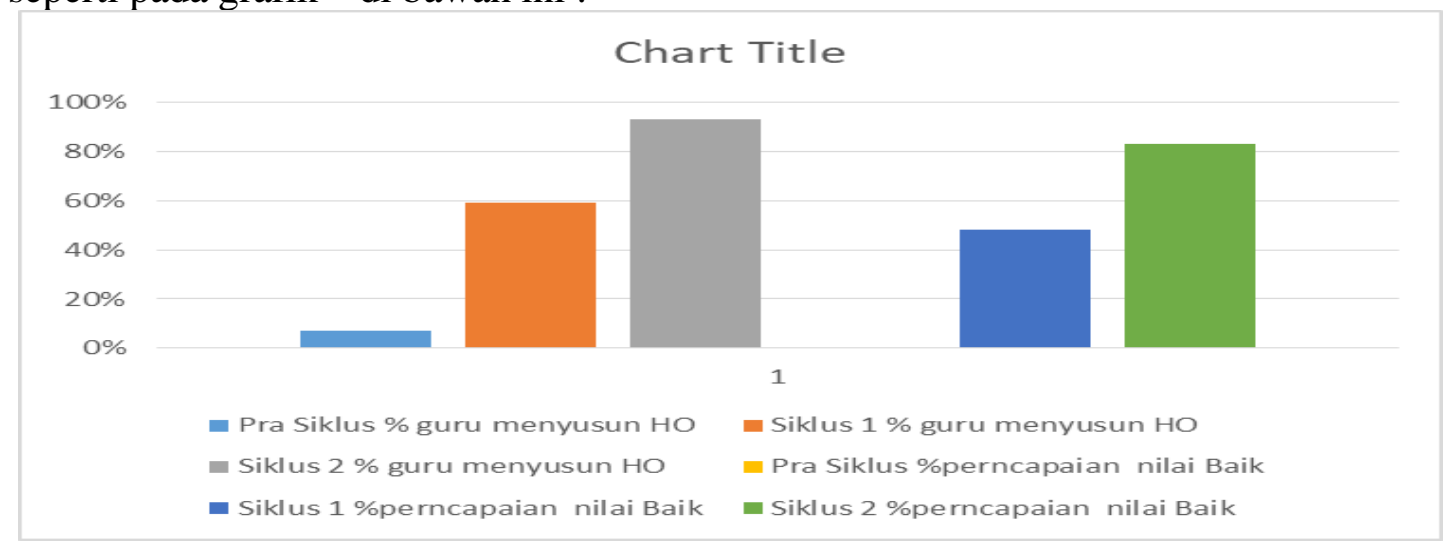

Gambar 3. Persentae guru menyusun hand out dan penilaian hand out pada materi pembelajaran pra siklus, siklus 1 dan siklus 2.

Dari pembahasan diatas dapat disimpulkan bahwa kemampuan guru-guru SMPN 1 Kecamatan Lareh Sago Halaban dalam menyusun hand out dapat ditingkatkan melalui kegiatan in house training (IHT) . 


\section{SIMPULAN DAN SARAN}

\section{Simpulan}

Era pandemi saat ini merupakan tantangan baru bagi dunia pendidikan, termasuk bagi guru, dengan pembelajaran jarak jauh (PJJ) baik darin atau luring kita dituntut untuk tetap melaksanakan pembelajaran yang berkualitas serta siswa bisa memperoleh apa yang mereka butuhkan dan penggunaan hand out dapat dijadikan sebagai salah satu sarana pemenuhan kebutuhan siswa tersebut. Hasil penelitian pada siklus 1 rata-rata porsentase 54\% dan pada siklus 2 rata-rata porsentase $88 \%$ sehingga dapat disimpulkan terjadi kenaikan sebesar 34\% . Dari hasil penelitian dapat disimpulkan In House Training (IHT) dapat meningkatkan kemampuan guru-guru SMPN 1 Kecamatan Lareh Sago Halaban dalam menyusun hand out.

\section{Saran}

Berdasarkan kesimpulan penelitian, beberapa saran dalam yang diajukan antara lain sebagai berikut, Pertama, untuk lebih efektif dan efisiennya sebuah kegiatan in house training disarankan peserta kegiatannya untuk diinapkan. Kedua, karena model in house training ini masih pada tatanan pengembangan konsep maka diperlukan adanya ujicoba model in house training secara lebih luas, untuk melihat lebih jauh efektivitas model in house training dalam meningkatkan kompetensi guru-guru.

\section{DAFTAR PUSTAKA}

Asrori, Mohammad. 2019. Penelitian tindakan Kelas. Bandung;PT Sandiata Sukses

Baharuddin. 2017. Pengembangan Profesionalisme Guru Melalui In House training. $\quad$ El-Idare : http://jurnal.radenfatah.ac.id/index.php/El-idare Journal of Islamic Education Management, Vol. 3 No. 2, pp 1-20 Desember 2017.

Departemen Pendidikan Nasional. 2000. Kamus Besar Bahasa Indonesia.

Departemen Pendidikan Nasional. 2007. Peraturan Mentri Pendidikan Nasional Republik Indonesia Nomor 16 tahun 2007 tentang Standar Kualifikasi dan Kompetensi Guru. Jakarta; Departemen Pendidikan Nasional.

Prasetyo Wisnu. 2017. "Pengembangan bahan Ajar Hand Out Melakukan Pekerjaan dengan Mesin Bubut di SMK PGRI 1 Yogyakarta”. 2017 https://core.ac.uk/download/pdf/78034912.pdf (diakses Kamis , 25 Juni 2020, Pukul 11. 26 WIB)

Waitlem dan Risman. 2017. Praktik Praktis Penulisan Karya Tulis Ilmiah untuk Guru. Padang. Kabarita

Widadi Martin. 2012. "Pengembangan Hand Out Pembelajaran Kerja Bangku di SMK Negeri 1 Seyegen”. 2012. 